\title{
Stealth Learning: Unexpected Learning Opportunities Through Games
}

\author{
Laura A. Sharp
}

Educators across the country struggle to create engaging, motivating learning environments for their Net Gen students. These learners expect instant gratification that traditional lectures do not provide. This leaves educators searching for innovative ways to engage students in order to encourage learning. One solution is for educators to use stealth learning in their classrooms to create engagement and motivation in students that would increase learning opportunities. This article will cover stealth learning topics including unexpected learning opportunities, benefits, academic performance, and use of games in the classroom, engagement, and motivation that educators can use in the $K-12$ setting.

One of the biggest challenges in today's classrooms is keeping Net Generation (Net Gen) students motivated and engaged long enough to learn the material (Prensky, 2007). The Net Generation, born after 1980 (Carlson, 2005), is a complex being characterized by a technological way of life. In order to reach these students and protect them from boredom, educators are constantly searching to find new techniques to motivate and engage students to foster a greater desire for school and learning (Annetta, 2008). Net Gens are impatient and extremely capable of multitasking; desiring a multifaceted classroom including games, courseware, a variety of search engines, and course content that is animated, interactive, and musical (Carlson, 2005). As teachers are preparing to teach Net Gens, they must align their teaching to the students' level in order to connect and make learning meaningful.

\section{STEALTH LEARNING}

Stealth learning is when an instructor uses clever, disguised ways to introduce learning objectives through non-traditional tools, such as games, to encourage students to have fun and learn. Students think they are merely playing, but they are simultaneously learning. So why use stealth learning? Anytime learning is presented and students are unaware they are learning, it is an unexpected benefit. According to Prensky (2007), young students primarily learn through play, games, and gaming activities that blend real world situations with traditional learning environments, for example, learning to take risks and make choices. Research indicates that games can encourage authentic learning situations in K-12 classrooms, which are beneficial to helping students develop enthusiasm for new curriculum and allowing students to envision mastering the content (Barab, Gresalif, \& Arici, 2009; Gee, 2005).

\section{UNEXPECTED LEARNING WITH GAMES}

With games being an original educational vehicle (Crawford, 1984), it is only natural to use them to teach students new information when students are unaware or uninterested in learning, thus stealth learning. Games have been used in learning to support K-12 state standards, goals, and outcomes while providing student engagement and authentic learning opportunities. Game play methodically provides the student with new and varied learning environments that meet his or her learning style (Annetta, 2008).

In high school classes, educators are assign- 
ing games as pre- and post-tests, reviews, and even as homework assignments (Annetta, 2008). There is documentation showing individuals learn best by doing, thus allowing students a hands-on opportunity which has proven to be beneficial (Annetta, 2008). Tapscott (1998) contends that Net Gens typically expect a more interactive and less linear approach to learning and when games are used in the classroom students have multiple learning opportunities allowing "schools to become a place to learn rather than a place to teach" (p. 143). Traditional lecture and quiz instruction models are inefficient in teaching higherorder problem-solving skills such as project management, negotiation, and decision making which are necessary for students destined for the business world (Allen, 2002). Games fit in almost every subject in today's classrooms because they accommodate various student-learning styles while encouraging complex skills such as decision-making, enabling students with disabilities to also utilize them.

\section{BENEFITS}

The benefits of gaming in the classroom include increased memory, class performance, social benefits, and improving the transfer of learning (Salies, 2002). Educators presume that students learn and use that knowledge in other contexts, but that is not always the case (Barnett \& Ceci, 2002). Students need to have the material learned in a variety of contexts in order to practice it, which is not the norm in a traditional classroom setting; in contrast, this becomes feasible in a game environment where students are encouraged to take risks and learn from them.

Created with collaborative and cooperative learning built into the overall experience, games offer an engaging environment for information assimilation (Clegg, 1991; Salies, 2002). Games allow an interactive structure that provides students rewards for problem solving and collaboration (Schwartzman, 1997), cooperative learning that encourages individual student accountability, and feedback processing (Millis \& Cottell, 1998). Through games, players learn that rules are a part of our daily lives (Rieber, Smith, \& Noah, 1998).

In a recent survey (Project Tomorrow, 2008), 320,000 students, 25,000 educators, 20,000 parents, and 3,300 school administrators stated that over half of the students from 3rd grade through 12th grade would benefit and learn from games. Only 3\% of elementary age students stated they do not play any type of game (Project Tomorrow, 2008). Of the K-12 educators surveyed, $11 \%$ admitted they were already using games in the classroom; however, numerous teachers stated they felt games meet different learning styles, teach critical thinking skills, and increase student engagement (Project Tomorrow, 2008). Over $50 \%$ of the educators surveyed indicated high interest in incorporating games in the classroom, while $6 \%$ of the teachers stated they felt games did not add any value in the classroom (Project Tomorrow, 2008). Besides the television, children are learning with games involving computer, console, online, and board games; educators are taking advantage of this interest by incorporating games in the classroom to increase student-learning experiences, making materials more current and relevant (Heim, Brandtzaeg, Kaare, Endestad, \& Torgersen, 2007).

Games methodically provide the student with new and varied learning environments that meet his or her learning style. Active learning through the use of gaming has shown a positive impact with students by allowing them to actively participate in a learning project instead of passively listening to lectures or watching videos with educators assigning games as pre- and post-tests, reviews, and even as homework assignments (Annetta, 2008). When K-12 students are learning to play games, they are in fact learning a new literacy or language that is defined above and beyond traditional reading and writing, but through multiple interactions including images, text, diagrams, symbols, and movement (Gee, 2007). These multiple interactions need correct interpretations for the student to master the game resulting in out of the box thinking and risk taking which are based on active learning. Active learning principle focuses on games requiring players to use active instead of passive learning and reflective thinking, which generates information from this type of learning through instant feedback and the opportunity to determine additional game solutions (Gee, 2007).

\section{ACADEMIC PERFORMANCE}

Educators need to present materials in an engaging and motivating manner that encourages exploration, experimentation, and knowledge building (Annetta, 2008). A meta-analysis through various studies of students in 14 K-12 school districts by Haystead and Marzano (2009) found using academic games gained 20\% in achievement scores. Learning through games involves requiring the student to develop vari- 
ous strategies in order to advance to the next level; however, the learning curve of the game includes interface, structure, and various strategies necessary to move forward in the game (Sharritt, 2008). Games arouse curiosity and interest, which educators should take advantage to generate enthusiasm, encourage competition, and increase student engagement (Marzano, 2007). Games offer numerous challenges for students regardless of student ability or level and help educators engage non-engaged students and refocus their attention on the curriculum (Marzano, 2007).

\section{GAMES IN THE CLASSROOM}

Even though using games is still relatively new in the classroom (Druckman, 1995), most students play games daily making it advantageous for teachers to learn how to incorporate gaming into their classrooms. Prensky (2007) listed reasons why games were engaging including providing structure, motivation, enjoyment, gratification, pleasure, intensity, learning, creativity, and social opportunities. Students respond to a number of learning activities during game play including facts, skills, judgment, behaviors, theories, reasoning, processes, creativity, language, systems, observation, and communication (Sharritt, 2008). When a student can be so engaged and motivated, this type of learning tool becomes an important part of the curriculum. Clegg (1991) pointed out the most important predictor of learning is the instructional context and not necessarily the actual game, but the collaborative and cooperative learning built into the overall experience, offering an engaging environment for information assimilation.

Games create competitive and collaborative situations making learning fun and engaging; meeting the many needs of the students (Weiss \& Loebbeck, 2008). During the early grades, teachers spend up to eight hours with their students each day; they could utilize the interactive and social aspects in games in order to realize additional learning in the classroom and use it to support other subjects (Klopfer, Osterweil, \& Salen, 2009). The only issue is the lack of time to play the game and move to advanced levels where the educational content becomes more challenging as most commercial games take several hours to complete (Charsky \& Ressler, 2011). One solution to this would be using a game clock or spreading the game across several class periods.

McDonald and Hannafin's (2003) research illustrated that by using educational games as review tools, the students were more interested and engaged; when students are more interested and engaged they are more willing to devote time to learn a new subject. By taking advantage of the students' enjoyment, educators are able to create a balance between learning, challenge, and learner satisfaction (Yip \& Kwan, 2006). Squire et al. (2003) suggest that the versatility of games fits into an educational environment as a pedagogical approach rather than a onetime situation. Games range from small-scale games used for demonstrations to larger style games that take up multiple class periods; teachers assign games as homework leaving students to confront the issues by themselves, or they use them as final exams (Squire et al., 2003).

\section{ENGAGEMENT AND MOTIVATION}

In order to create a memory, an individual needs to have an emotional involvement to the learning, which causes a chemical reaction in the brain (Ledoux, 1998). Individuals learn best by doing, so when educators allow students a hands-on opportunity it has been proven beneficial (Annetta, 2008). While the use of games in the classroom is not meant to replace all teaching strategies; however, games can be used as an engaging and motivating supplement that provides background and content in an environment in which they are familiar and comfortable (Annetta, 2008). Games potentially enhance and can fill gaps between school and the real world through higher-order problem solving. Skills addressed through games are missing in traditional lecture style of instruction (Berson, 1996).

When motivated and engaged, even the most uninterested student is willing to face the challenges created by games to solve problems (Kara-Soteriou, 2010). These uninterested students will often complain about and refuse to complete homework, would rather spend a number of hours devising strategies and having social interactions with other players (Kara-Soteriou, 2010). Students have time to reflect between game sessions, as they likely will have conversations with their classmates about strategies. Additional play/practice can transfer the generalizable skills with minimal support.

When educators use games, they improve upon the traditional education system encouraging students to keep trying even when they lose and practice until they have mastered the content. Students learn at different paces and will achieve mastery at dissimilar times. Through various learning styles, games touch 
on visual, auditory, and kinesthetic learning styles. By creating an environment that actively encourages peers to teach and learn from each other, collaborative play offers students who have already mastered the elements a chance to become the teacher and instruct their classmates. Games are played because they are fun and offer learners a choice about how and what they learn. Instigating learning through play is easier because games employ artifacts permitting students to feel they are playing instead of wasting time learning irrelevant curriculum (Aldrich, 2009).

\section{BOARD GAMES IN THE CLASS}

Board games are brain type games including puzzles, word games, and other games that have learning possibilities with a short learning curve and only taking a few minutes to play (Cai, 2006). Games engage students in healthy activities that challenge the mind, teach social skills, and promote active learning while having fun. Some tradition games that can be used in elementary classrooms include:

- Connect 4C - counting, lines, diagonals, squares, competition

- Crosswords - vocabulary words, definitions

- Darts - large motor skills, counting, targets

- Dice - counting or add/subtract/multiply each cube

- Dominoes - add/subtract each side

- Hang Man - vocabulary words, capitals, states, people, places, and things

- Jacks - fine motor skills and counting

- MemoryC - matching (pieces can be made with pictures, words, or numbers)

- Trouble(C) - counting and consequences

- Word Search - vocabulary words, definitions

- YahtzeeC - counting and matching numbers

(Hasbro, 2011).

Regardless of the game selected, each can be used to teach important lessons including problem solving, abstract decision-making, flexible planning, consequences, creativity, thinking logically, and efficiently. Here are several of the games used with middle and high school students along with the skills addressed with each of them:

- Crosswords - vocabulary words, definitions

- Word Search - vocabulary words, definitions

- Aggravation (C - gravity, strategy
- Cranium (C) - a game where everyone can show their strengths: acting, drawing, wordsmith, or knowledge

- Jenga@ - fine motor skills and matching

- Mouse Trap (C) - cause and effect (chain reaction)

- Risk@ - teaching world geography and strategy

- ScrabbleC - teaching spelling and vocabulary (Hasbro, 2011).

If educators are looking for whole class participation, consider that there are great templates for blank board games that are downloadable and able to be modified for class needs. Another option is to assign a cooperative group to create a review game for a certain section of the material.

\section{CONCLUSION}

Every time a student is unengaged, a teaching moment is lost. In order to reach Net Gen students, educators are always searching to find new techniques to motivate and engage students (Annetta, 2008; Prensky, 2007). Currently, through games, students are able to learn various skills including spelling, vocabulary words, counting, money management, history, social studies, using what is given and not complaining, following rules, waiting turns, problem solving, communication skills, trivia, telling time, matching colors or shapes, and exhibiting appropriate behaviors by playing board games. Games fit in almost every subject in today's classrooms creating unexpected or stealth learning opportunities while accommodating various student-learning styles and encouraging complex skills such as decision making which allows even students with disabilities to utilize them. 


\section{Author Biography}

Laura Sharp is an adjunct professor in the College of Education at Grand Canyon University teaching courses in special education. She received her M.Ed. in Cross Categorical Special Education from Grand Canyon University and is in the final year of an Ed.D in Organizational Leadership - Higher Education. Laura's career has included teaching alternative, gifted and talented, ELL, and special education (mild, moderate, severe, and profound) K-12, undergraduate, and graduate level students. Her research interest includes the Gamucation, social presence, learning styles, student engagement, motivation, and online learning. One of Laura's passions is sharing her knowledge of teaching and curriculum with preservice teachers, mentoring and coaching new instructors through their first year, and helping these new teachers engage and motivate their students. 


\section{References}

Aldrich, C. (2009). Learning online with games, simulations, and virtual worlds: Strategies for online instruction. San Francisco, CA: Jossey-Bass

Allen, M. (2002, January). Discovery learning: Repurposing an old paradigm - How to make learning active and student-centered. Learning and Training Innovations Magazine. Retrieved from http:// www.elearningmag.com/

Annetta, L. A. (2008). Video games in education: Why they should be used and how they are being used. Theory Into Practice, 47(3), 229-239. doi:10.1080/00405840802153940

Barab, S. A., Gresalfi, M., \& Arici, A. (2009). Why educators should care about games. Educational Leadership, 67(1), 76-80.

Barnett, S. M., \& Ceci, S. J. (2002). When and where do we apply what we learn? A taxonomy for far transfer. Psychological Bulletin, 128(4), 612-637. doi:10.1037/0033-2909.128.4.612

Berson, M. J. (1996). Effectiveness of computer technology in the social studies: A review of the literature. Journal of Research on Computing in Education, 28(4), 486-499.

Cai, Y. (2006) Electronic gaming in the digital home: A multiclient study.Retrieved from Parks Associates website: http://www.park sassociates.com/index.php

Carlson, S. (2005, October 7). The Net Generation goes to college. The Chronicle of Higher Education, 52(7), A34. Retrieved from http://content.imamu.edu.sa/Scholars/it/net/the_net_generation.pdf

Charsky, D., \& Ressler, W. (2011). "Games are made for fun": Lessons on the effects of concept maps in the classroom use of computer games. Computers \& Education, 56(3), 604-615. doi:10.1016/j.compedu.2010.10.001

Clegg, A. A. (1991). Games and simulations in social studies education. In J. P. Shaver (Ed.), Handbook of research on social studies teaching and learning (pp. 523-529). New York, NY: Macmillan Publishing Company.

Crawford, C. (1984). The art of computer game design: Reflections of a master game designer. Berkeley, CA:McGraw-Hill Osborne Media.
Druckman, D. (1995). The educational effectiveness of interactive games. In D. Crookall \& K. Arai (Eds.), Simulation and gaming across disciplines and cultures: ISAGA at a watershed (pp. 178187). Thousand Oaks, CA: Sage Publications.

Gee, J. P. (2005). What would a state of the art instructional video game look like? Journal of Online Education, 1(6).

Gee, J. P. (2007). What video games have to teach us about learning and literacy (2nd ed.). New York, NY: Palgrave Macmillan.

Hasbro. (2011). Find a game or puzzle. Retrieved from http://www. hasbro.com/games/en_US/shop/find-a-game.cfm

Haystead, M. W., \& Marzano, R. J. (2009). Meta-analytic synthesis of studies conducted at Marzano Research Laboratory on instructional strategies. Retrieved from Marzano Research Laboratory website: http://www.marzanoevaluation.com/files/Instructional_Strategies_ Report_9_2_09.pdf

Heim, J., Brandtzaeg, P. B., Kaare, B. H., Endestad, T., \& Torgersen, L., (2007).

Children's usage of media technologies and psychosocial factors. New Media \& Society, 9(3), 425-454. doi;10.1177/1461444807076971

Kara-Soteriou, J. (2010). Computers in the classroom: Video games for the disengaged (and not only) students. The NERA Journal, 45(2), 94-101.

Klopfer, E., Osterweil, S., \& Salen, K. (2009). Moving learning games forward: Obstacles, opportunities \& openness. Retrieved from http://www.educationarcade.org/

LeDoux, J. (1996). The emotional brain. New York, NY: Simon \& Schuster.

Marzano, R. J. (2007). The art and science of teaching: A comprehensive framework for effective instruction. Alexandria, VA: Association for Supervision and Curriculum Development.

McDonald, K. K., \& Hannafin, R. D. (2003). Using web-based computer games to meet the demands of today's high-stakes testing: A mixed method inquiry. Journal of Research on Technology in Education, 35(4), 459-472.

Millis, B. J., \& Cottell, P. G. (1998). Cooperative learning for higher education faculty. Phoenix: AZ: Orynx Press. 
Prensky, M. (2007). Digital game-based learning. St. Paul, MN: Paragon House Publishers.

Project Tomorrow. (2008). Speak up 2007 for students, teachers, parents \& school leaders: Selected national findings- April 8, 2008. Retrieved from the Project Tomorrow website: http://www. tomorrow.org/speakup/speakup_reports.html

Rieber, L. P., Smith, L., \& Noah, D. (1998). The value of serious play. Educational Technology, 38(6), 29-37.

Salies, T. G. (2002). Simulations/gaming in the EAP writing class: Benefits and drawbacks. Simulation \& Gaming, 33(3), 316-329. doi:10.1177/104687810203300306

Schwartzman, R. (1997). Gaming serves as a model for improving learning. Education, 118(1), 9-18.

Sharritt, M. J. (2008). Students' use of social and cognitive affordances in video game play within educational contexts: Implications for learning (Doctoral dissertation). Retrieved from Proquest Dissertations and Theses Database. (AAT 3312596)

Squire, K. \& Jenkins, H. (2003). Harnessing the power of games in education. Insight, 3(1), 5-33.

Tapscott, D. (1998). Growing up digital: The rise of the net generation. New York, NY: McGraw-Hill.

Weiss, T., \& Loebbecke, C. (2008). Online gaming adoption in competitive social networks: Combining the theory of planned behavior and social network theory. Proceedings of the Fourteenth Americas Conference of Information Systems, Toronto, ON, Canada, August 14th-17th, 2008.

Yip, F. W. M., \& Kwan, A. C. M. (2006). Online vocabulary games as a tool for teaching and learning English vocabulary. Educational Media International, 43(3), 233-249. doi:10.1080/09523980600641445 